\title{
PENGEMBANGAN BUKU REFERENSI MENULIS FAKTUAL BERBASIS MULTILITERASI
}

\author{
Ary Kristiyani \\ Fakultas Bahasa dan Seni Universitas Negeri Yogyakarta \\ email: arykristiani@uny.ac.id
}

\begin{abstract}
Abstrak
Penelitian ini bertujuan untuk mendeskripsikan pembelajaran menulis faktual, menghasilkan buku referensi menulis faktual berbasis multiliterasi dan mendeskripsikan pendapat pakar terhadap produk tersebut. Penelitian ini menggunakan metode penelitian pengembangan. Teknik pengumpulan data dilakukan melalui studi pustaka, studi lapangan, wawancara, dan angket. Analisis data yang digunakan dalam penelitian ini adalah analisis kualitatif dan kuantitatif. Analisis kualitatif digunakan untuk mendeskripsikan data kualitatif seperti data wawancara dan analisis dokumen. Analisis kuantitatif digunakan untuk mengolah data angket. Prosedur pengembangan mengikuti langkah desain produk, tahap uji materi dan merevisi produk. Hasil penelitian menunjukkan bahwa pembelajaran menulis faktual menggunakan sumber referensi di internet, Pedoman Umum Ejaan Bahasa Indonesia, Kamus Besar Bahasa Indonesia, dan Buku Sekolah Elektronik. Buku referensi menulis faktual berbasis multiliterasi disusun secara runtut dan detail untuk membantu pembaca memahami, menggunakan, dan mengaplikasikan dalam praktik menulis faktual. Buku referensi menulis faktual berbasis multiliterasi dalam kategori layak digunakan dengan revisi, yaitu perbaikan pada penerapan multiliterasi.
\end{abstract}

Kata kunci: menulis faktual, multiliterasi, buku referensi

\section{DEVELOPING MULTILITERACIES BASED WRITING FACTUAL REFERENCE BOOK}

\begin{abstract}
This study was aimed at describing the factual writing of the students before using multiliteracies based factual reference book, generating multiliteracies based factual reference book, and describing the expert judgements of the reference book. This study used Research and Development (R\&D) method. The data were collected through literature studies, field studies, interviews, and questionnaires. The data analysis methods used were qualitative and quantitative analysis. The qualitative analysis was used to describe the data from the interview and the documentation. The quantitative analysis was used to analyze the questionnaire data. The stages of this study were product design, expert judgement, and revision. The result of the study shows that before the use of multiliteracies based reference book, the learning materials are limited to the reference sources on the internet, General Guidelines for Indonesian Spelling, Indonesian Dictionary, and Electronic School Textbooks. Multiliteracies based writing factual reference book is arranged in coherence and detail to help readers in understanding, using, and applying the factual writing texts. The expert judgements on the product show that the product is categorized into feasible with revision. Some improvements are needed in the multiliteracies application.
\end{abstract}

Keywords: factual writing, multiliteracies, reference book 


\section{PENDAHULUAN}

Tahun 2013 telah dikeluarkan Peraturan Menteri Pendidikan dan Kebudayaan Nomor 73 Tahun 2013 tentang Pedoman Kerangka Kualifikasi Nasional (KKNI). Peraturan ini mengamanatkan penjenjangan kualifikasi yang dapat menyandingkan, menyetarakan, dan mengintegrasikan capaian pembelajaran dari jalur pendidikan nonformal, pendidikan formal, dan/atau pengalaman kerja ke dalam jenis dan jenjang pendidikan tinggi. Peraturan ini juga mengamanatkan adanya profil lulusan dan capaian pembelajaran agar arah dari pembelajaran pada setiap prodi lebih jelas dan terukur (Kurikulum KKNI, 2015, pp. i-ii).

Kurikulum Berbasis KKNI pada Mata Kuliah Menulis Faktual bertujuan memberikan kompetensi kepada mahasiswa dalam hal penguasaan teori dan praktik menulis faktual. Garis besar materi meliputi: teori dan praktik beberapa jenis penulisan faktual, pengajaran menulis faktual, evaluasi menulis faktual, dan penelitian dalam penulisan faktual. Perkuliahan dilakukan dengan pendekatan genre dan pendekatan proses, sedangkan penilaian terutama dilakukan terhadap pemberian tugas-tugas yang terkumpul dalam portofolio, tes tengah semester, dan tes akhir semester. Terdapat tujuh teks dalam menulis faktual, yaitu menulis teks deskripsi, narasi, eksplanasi, eksposisi, recount, prosedur, dan berita. Proses pembelajaran yang dilakukan selama ini menggunakan pendekatan proses dan genre, namun hasilnya belum maksimal.

Materi yang disampaikan dosen di kelas, bukan satu-satunya sumber informasi pengetahuan yang diperoleh mahasiswa. Mahasiswa dapat memperoleh materi kuliah yang tersebar pada berbagai referensi di perpustakaan, internet, atau perpustakaan digital (Syamsi, Setiawan, dan Suryaman, 2017). Selaras dengan pendapat tersebut bahwa buku referensi menulis faktual selama ini mengambil dari berbagai sumber, baik cetak maupun elektronik. Dari berbagai referensi tersebut, dosen membuat ringkasan dalam bentuk slide. Pentingnya buku ajar atau buku referensi adalah menyiapkan mahasiswa yang terampil dalam bidang yang ditekuninya, baik secara praktis maupun teoretis. Sejalan dengan dengan pendapat Moedjiarto (1998) bahwa peningkatan buku ajar berbanding lurus dengan peningkatan mutu perkuliahan. Hal ini diperkuat dengan pendapat Prihandoko, Slamet, dan Winarno (2017) bahwa materi dapat dikembangkan melalui bahan ajar dan menjadi solusi paling relevan mengingat keberagaman kompetensi, kreativitas, dan pola mengajar pendidik. Pemahaman tentang buku teks atau referensi menjadi indikator keberhasilan dalam pembelajaran. Pemahaman terhadap buku teks dapat dilakukan dengan cara membaca (Haryadi, 2003). Membaca yang dimaksud bukan melisankan bahan bacaan tetapi membaca pada tingkatan pemahaman. Bahan bacaan yang memudahkan pemahaman mahasiswa diperlukan untuk mencapaian kompetensi lulusan. Dengan demikian, perlu inovasi baru tentang buku referensi yang dikembangkan sehingga pembelajaran dapat tercapai secara maksimal dan pembelajaran lebih bervariasi.

Berfokus pada permasalahan tersebut, perlu dikembangkan buku referensi menulis faktual berbasis multiliterasi sehingga dapat ditemukan pola pembelajaran yang tepat dan tercapai tujuan pembelajaran secara maksimal. Dengan demikian, buku referensi menulis faktual berbasis multiliterasi mampu memotivasi dan membantu mahasiswa belajar secara mandiri dan mengembangkan kemampuan menulis teks faktual berdasarkan buku referensi tersebut. Penelitian ini bertujuan untuk mendeskripsikan pembelajaran 
menulis faktual, buku referensi menulis faktual berbasis multiliterasi, dan pendapat pakar dan praktisi terhadap produk tersebut.

Bahan ajar terdiri atas pengetahuan, keterampilan, dan sikap yang harus dipelajari peserta didik untuk mencapai standar kompetensi yang telah ditentukan. Bahan ajar disusun untuk memudahkan pencapaian tujuan pembelajaran (Leksono, Syachruroji, \& Marianingsih, 2015). Suryaman (2012, pp. 1-2) mengemukakan bahwa terdapat dua klasifikasi buku pendidikan, yakni buku teks pelajaran dan buku nonteks pelajaran. Buku teks pelajaran adalah buku acuan wajib untuk digunakan di sekolah yang memuat materi pembelajaran dalam rangka peningkatan keimanan dan ketakwaan, budi pekerti dan kepribadian, kemampuan penguasaan ilmu pengetahuan dan teknologi, kepekaan dan kemampuan estetis, potensi fisik, dan kesehatan yang disusun berdasarkan standar nasional pendidikan. Lebih lanjut dikatakan, buku nonteks pelajaran meliputi buku pengayaan, buku panduan pendidik, dan buku referensi. Buku pengayaan adalah buku-buku yang dapat memperkaya peserta didik dalam bidang pengetahuan, keterampilan, dan kepribadian. Jenis buku pengayaan meliputi buku pengetahuan, buku keterampilan, dan buku kepribadian. Buku panduan pendidik adalah buku yang memuat prinsip, prosedur, diskripsi materi pokok, dan model pembelajaran untuk digunakan oleh para pendidik. Jenis-jenisnya meliputi buku pendidikan dan pembelajaran, media pembelajaran, evaluasi pembelajaran, serta penelitian pendidikan.

Buku referensi adalah buku yang isi dan penyajiannya dapat digunakan untuk memperoleh informasi tentang ilmu pengetahuan, teknologi, seni, dan budaya secara dalam dan luas. Buku referensi menurut Kamus Besar Bahasa Indonesia (KBBI) Daring (2016) bermakna buku rujukan.
Jenis-jenisnya meliputi ensiklopedi, kamus, atlas, aturan/perundang-undangan. Sejalan dengan pendapat tersebut, Suryaman (2012, p. 32) menyatakan seorang penulis buku referensi (kamus, ensiklopedia, peta) harus memerhatikan perkembangan ilmu yang mutakhir, sahih, dan akurat dalam bidang kartografi; perkamusa; atau ensiklopedia. Penulis seharusnya menggunakan datadata, konsep, atau teori yang mutakhir, tidak terdapat kesalahan konsep yang fatal, akurat dalam mendeskripsikan bahasan. Selain itu, materi atau isi buku referensi harus lengkap komprehensif, dan konsisten sesuai dengan karakteristik bidang atau ruang lingkup buku referensi. Kekomplitan materi meliputi masuknya pembahasan keseluruhan lema (entry) yang penting dan relevan. Kekomprehensifan materi isi bermakna pembahasan yang menyeluruh untuk setiap lema. Konsistensi dalam pembahasan artinya bahwa keseluruhan pembahasan berada dalam jalur bidang ilmunya.

Menulis faktual berdasarkan KBBI Daring (2016) adalah menulis berdasarkan fakta. Menulis faktual merupakan sebuah proses komunikasi atau pemberian ide, gagasan, dan pikiran dengan bahasa yang dapat dipahami oleh orang lain dalam bentuk atau wujud bahasa tulis yang berdasarkan fakta-fakta. Menulis faktual pada hakikatnya menulis berbasis pendekatan proses dan menulis berbasis pendekatan genre. Selaras dengan hal itu, Pardiyono (2007, p. 2) menjelaskan genre untuk teks tertulis harus memiliki tujuan yang jelas; semua informasi, pesan, dan ide disajikan secara efektif dalam bentuk teks tertentu seperti deskripsi, recount, naratif, eksposisi, prosedur, anekdot, berita, dan diskusi.

Ragam menulis faktual di antaranya deskripsi, narasi, recount, eksposisi, eksplanasi, prosedur, dan berita. Genre teks 
dibedakan berdasarkan tujuan, yaitu naratif memiliki tujuan menghibur dan memberikan pelajaran tentang suatu kejadian. Genre recount bertujuan memberikan informasi tentang kegiatan menarik di masa lalu. Genre deskripsi memiliki tujuan memberikan gambaran tentang sesuatu hal. Genre prosedur bertujuan memberikan instruksi membuat sesuatu atau melakukan suatu pekerjaan secara runtut dan efektif. Genre eksplanasi memberikan informasi tentang proses pembentukan suatu hal. Genre eksposisi bertujuan menyampaikan argumen atau opini tentang suatu hal. Adapun genre berita mempunyai tujuan memberikan informasi tentang peristiwa atau kejadian di masyarakat (Pardiyono, 2007, p. 18).

Berbasarkan paparan tersebut dapat disimpulkan bahwa menulis faktual adalah perkuliahan yang menghasilkan ragam teks yang memaparkan fakta dengan menggunakan pendekatan proses dan pendekatan genre. Pendekatan proses tampak pada kegiatan menulis, mulai dari pramenulis, menulis, dan pascamenulis sedangkan pendekatan genre didasarkan pada jenis teks.

\section{Progress in International Reading}

Literacy Study (PIRLS) adalah studi literasi yang dirancang untuk mengetahui kemampuan peserta didik dalam memahami bermacam ragam bacaan. Perkembangan pengetahuan, pengertian dan pemahaman literasi terus dikembangkan dan diaplikasikan pada berbagai bidang, di antaranya literasi di bidang informasi lebih dikenal dengan literasi informasi, literasi media, literasi sains, literasi matematis, dan literasi statistis (melek statistik) (Takaria \& Talakua, 2018). Demikian perkembangan pengetahuan hingga melahirkan konsep multiliterasi.

Multiliterasi merupakan paradigma baru dalam pembelajaran literasi yang lahir berdasarkan konsep multimodal dalam pendidikan (Sari, Suryaman, \& Lestyarini, 2011, p. 1). Lebih lanjut dikatakan, masyarakat multikultur dengan akses mobilitas yang tanpa batas dan ditunjang oleh teknologi memberikan beragam implikasi pada berkembangnya pengelolaan pembelajaran multiliterasi. Model pembelajaran multiliterasi adalah model pembelajaran yang bertujuan untuk mengembangkan dan mengoptimalkan kemampuan berpikir kritis siswa, pemahaman konseptual siswa, berpikir kreatif siswa, serta kolaboratif dan komunikatif antarsiswa (Azizah, Abidin, \& Yunansah, 2015). Lebih lanjut dikatakan, model pembelajaran multiliterasi dapat digunakan karena mampu mengembangkan dan mengoptimalkan kemampuan-kemampuan siswa dalam menghadapi pendidikan pada abad XXI. Selain itu, model pembelajaran ini dapat membiasakan siswa untuk menulis suatu karangan yang memiliki nilai ilmu pengetahuan.

Sejalan dengan hal tersebut, Abidin (2014) mengatakan bahwa pembelajaran berbasis multiliterasi sangat bermanfaat dalam menciptakan kondisi pembelajaran yang berbasis inkuiri, kritis, dan sekaligus dapat mengembangkan penggunaan kemampuan multiliterasi siswa. Lestyarini (2011, p. 1) mengatakan bahwa konsep multimodal dalam pendidikan mengacu pada banyaknya jenis bahan yang dapat digunakan dalam pembelajaran literasi berimplikasi pada munculnya konsep multiliterasi. Lebih lanjut dikatakan, ada empat aspek dalam kajian multiliterasi yaitu situated practice, overt instruction, critical framing of cultural and social context, transformed practice yang tercermin dalam conventional reading and writing, digital lieracy, visual literacy, dan critical literacy dalam praktik multiliterasi di kelas.

Pemahaman tentang konsep multiliterasi dari paparan di atas dapat disimpulkan 
bahwa multiliterasi menjadi tuntutan pembelajaran di era global. Penguasaan baca dan tulis dari berbagai sumber mendukung insan yang literat. Dengan demikian, perlu dikembangan buku referensi menulis faktual yang mampu mengakomodasi tuntutan pembelajar yang literat. Buku referensi ini sebagai alternatif rujukan untuk pemahaman menulis faktual berbasis multiliterasi.

\section{METODE}

Metode penelitian yang digunakan adalah pengembangan (Research and Development/R\&D). Langkah-langkah penelitian dan pengembangan ditunjukkan pada Gambar 1.

Prosedur pengembangan yang dilakukan dalam penelitian ini menggunakan prosedur pengembangan yang paling sederhana, yakni mengindentifikasi potensi masalah, mengumpulkan data, desain produk yang dikembangkan berupa buku referensi menulis faktual berbasis multiliterasi, validasi produk oleh ahli, dan revisi produk. Adapun teknik pengumpulan data dilakukan melalui studi pustaka, studi lapangan, wawancara, dan kuesioner.
Analisis data dengan cara analisis kualitatif dan kuantitatif. Analisis kualitatif digunakan untuk mendeskripsikan data kualitatif seperti data wawancara dan data dokumen Analisis kuantitatif digunakan untuk mengolah data angket.

Studi pendahuluan dilakukan untuk mengetahui berbagai data yang dibutuhkan terkait dengan buku referensi yang selama ini digunakan pada Mata Kuliah Menulis Faktual. Studi pendahuluan dalam penelitian ini dilakukan berdasarkan studi pustaka, studi lapangan, dan kajian kurikulum. Studi pustaka yang dilakukan untuk mendeskripsikan data-data yang terkait buku referensi menulis faktual yang telah digunakan saat ini.

Studi lapangan juga dilakukan untuk data autentik penggunaan buku referensi menulis faktual. Selian kedua studi tersebut, perlu dilakukan kajian kurikulum sebagai acuan pengembangan bahan ajar. Kurikulum KKNI Perguruan Tinggi menjadi pedoman untuk merancang desain buku referensi menulis faktual berbasis multiliterasi. Pengembangan awal produk meliputi analisis tujuan dan analisis kemampuan. Analisis tujuan

Gambar 1. Langkah-Langkah Penelitian Research and Development (R\&D)

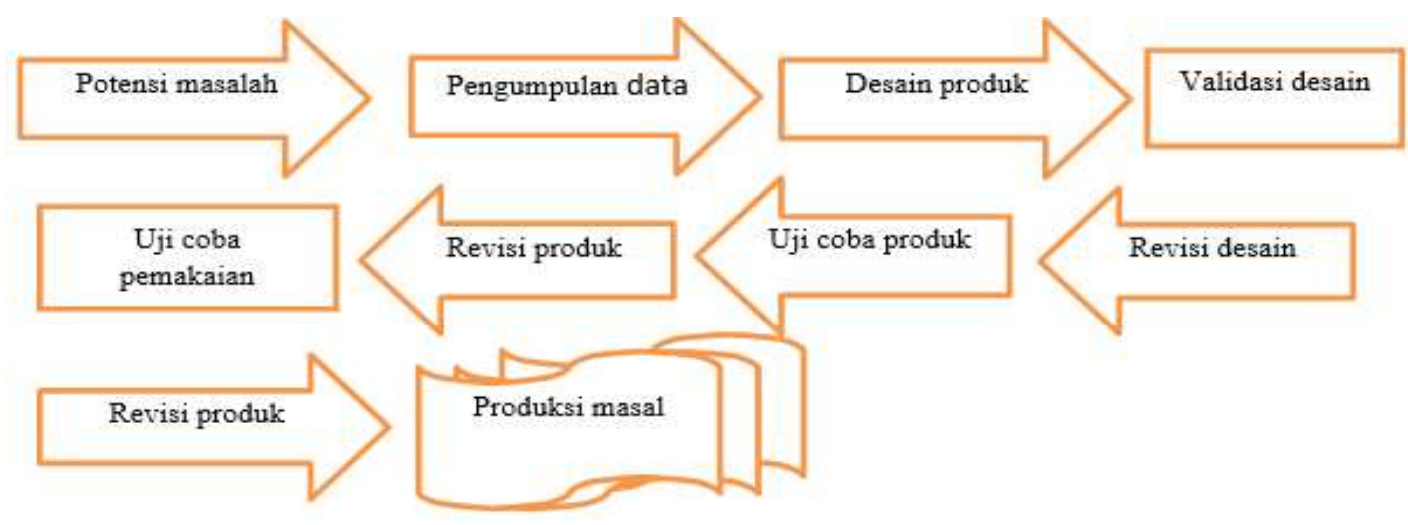

Keterangan: Sumber Sugiyono (2011, p. 298) 
dilakukan untuk merumuskan tujuan yang dicapai dalam penelitian pengembangan. Tujuan yang dicapai adalah terwujudnya buku referensi menulis faktual berbasis multiliterasi. Adapun alur penelitian dipaparkan dalam Tabel 1. Tahapan ini memberikan gambaran pengembangan buku referensi menulis faktual berbasis multiliterasi sehingga menghasilkan produk yang lengkap dan praktis digunakan oleh mahasiswa.

\section{HASIL PENELITIAN DAN PEMBAHASAN}

Capaian pembelajaran Menulis Faktual yang dikembangkan meliputi. Pertama, sikap. Menunjukkan sikap bertanggung jawab atas pekerjaan di bidang keahliannya secara mandiri. Kedua, pengetahuan. Menguasai konsep teoretis kebahasaan dan kesastraan untuk pengembangan kemampuan berkomunikasi lisan dan tulisan dalam berbagai keperluan yang mencakup teori dan praktik beberapa jenis penulisan faktual, pengajaran menulis faktual, evaluasi menulis faktual, dan penelitian dalam penulisan faktual. Ketiga, keterampilan. Mampu mengaplikasikan konsep teoretik kebahasaan dan kesastraan untuk pengembangan kemampuan berkomunikasi lisan dan tulisan dalam berbagai keperluan khususnya dalam praktik menulis faktual.

Distribusi Mata Kuliah Menulis Faktual diberikan kepada mahasiswa pada tingkat atau semester 3 dengan kode
PBS6330. Mata Kuliah Menulis diberikan setelah pemerolehan keterampilan yang lain, seperti menyimak, berbicara, dan membaca. Menulis Faktual memiliki beban 3 SKS (Sistem Kredit Semester) yang dirinci 2 SKS teori dan 1 SKS praktik. Kurikulum KKNI mengacu pada munculnya profil lulusan. Profil lulusan Program Studi Sarjana Pendidikan Bahasa dan Sastra Indonesia adalah sarjana yang ahli dalam bidang ilmu bahasa dan sastra Indonesia serta pendidikan bahasa dan sastra Indonesia yang ditransformasikan kepada orang lain, baik lisan maupun tulisan, baik afektif, psikomotorik, maupun pengetahuan sehingga mampu menciptakan masyarakat berliterasi tinggi.

Selain analisis terhadap kurikulum, gambaran awal pembelajaran menulis faktual diperoleh dari data wawancara kepada mahasiswa. Instrumen wawancara disusun untuk menggali pembelajaran menulis faktual, bahan ajar yang digunakan dalam menulis faktual, ketersediaan bahan dan kemudahan menggunakan bahan ajar menulis faktual, pemahaman tentang ragam menulis faktual, membedakan, dan evaluasi pembelajaran menulis faktual, serta paparan pendapat mahasiswa tentang bahan ajar menulis faktual yang menarik dan mudah dipahami. Wawancara dilakukan pada mahasiswa Program Studi Bahasa dan Sastra Indonesia Universitas Negeri Yogyakarta Semester Gasal yang

Tabel 1

Tahapan Penelitian Pengembangan Buku Referensi Menulis Faktual Berbasis Multiliterasi

\begin{tabular}{llll}
\hline \multicolumn{1}{c}{ Tahap 1 } & \multicolumn{1}{c}{ Tahap 2 } & \multicolumn{1}{c}{ Tahap 3 } & \multicolumn{1}{c}{ Tahap 4 } \\
\hline Studi Pendahuluan & Merancang produk & Validasi desain & Revisi \\
1. Studi pustaka & Desain produk berupa & $\begin{array}{l}\text { 1. Uji kelayakan } \\
\text { materi oleh ahli }\end{array}$ & Memperbaiki \\
2. Studi lapangan & buku referensi & $\begin{array}{l}\text { 2. Uji pengguna } \\
\text { terbatas }\end{array}$ & \\
3. Kajian kurikulum & & & \\
& & &
\end{tabular}


sedang menempuh Mata Kuliah Menulis Faktual.

Data wawancara tentang "bagaimana pembelajaran menulis faktual di kelas saudara?" Berikut jawaban mahasiswa tentang pembelajaran menulis faktual yakni pembelajaran berlangsung baik, pemaparan materi jelas, dan terdapat penambahan wawasan tentang penulisan yang benar yaitu penggunaan kalimat yang efektif, penerapan ejaan yang tepat, dan pengembangan paragraf yang runtut dan padu. Pembelajaran menulis faktual tidak hanya diberikan secara teori tetapi mahasiswa juga praktik menulis dan melakukan evaluasi pembelajaran menulis faktual. Pembelajaran sesuai dengan Rencana Perkuliahan Semester (RPS). Pembelajaran dilakukan secara efektif dengan memberikan contohcontoh sehingga memudahkan mahasiswa memahami materi menulis faktual.

Adapun data tentang buku referensi yang sudah digunakan oleh mahasiswa dalam menulis faktual dapat dilihat dari jawaban mahasiswa bahwa buku yang digunakan masih terbatas pada Buku Sekolah Elektronik (BSE), Pedoman Umum Ejaan Bahasa Indonesia (PUEBI), sumber bacaan dari internet, Kamus Besar Bahasa Indonesia. Selain itu, mahasiswa mengalami kesulitan dalam memahami buku referensi yang tersedia. Kesulitan terkait bahasa yang digunakan dalam buku referensi kurang sederhana dan penggunaan kalimat yang tidak efektif sehingga memungkinkan kesulitan memahami materi. Kendala lain yang dihadapi mahasiswa dalam memahami buku referensi menulis faktual yang telah tersedia adalah sistematika yang berbeda antara sumber referensi yang satu dengan yang lain.

Mahasiswa telah memahami materi dalam menulis faktual yaitu tentang ragam teks faktual, definisi teks, struktur teks, dan melakukan evaluasi pembelajaran menulis faktual. Materi diperoleh dari perkuliahan Menulis Faktual yang diberikan oleh dosen melalui slide (ringkasan dari berbagai sumber bacaan). Mahasiswa juga diberikan latihan mengevaluasi masing-masing teks menulis faktual yang disusun berdasarkan indikator yang relevan yaitu struktur teks, penggunaan ejaan yang benar, diksi yang bervariasi, pengembangan paragraf yang runtut dan padu, serta penggunaan struktur kalimat yang efektif.

Menurut mahasiswa buku referensi menulis faktual yang menarik dan mudah dipahami adalah buku yang menyediakan contoh teks beserta penjelasan bagianbagian struktur teks. Selain itu, penggunaan bahasa yang sederhana disertai ilustrasi dan contoh teks berdasarkan objek yang ada di sekitar penulis serta tips menulis berbagai teks menulis faktual yang benar. Mahasiswa juga berpendapat bahwa penggunaan media, baik visual dan audiovisual menjadi daya tarik dalam memahami ragam teks faktual dan penyajian materi secara runtut.

Selain itu, mereka berharap ada buku referensi menulis faktual yang memuat penilaian setiap teks ragam faktual dan penelitian dalam penulisan faktual. Berdasarkan hasil wawancara kepada mahasiswa dijadikan tolak ukur peneliti untuk mengembangkan buku referensi yang menarik, mudah dipahami, dapat dipelajari secara mandiri, mampu mempraktikkan kegiatan menulis ragam faktual, mampu mengevaluasi setiap ragam teks faktual, dan memilih ragam teks fakual sebagai objek penelitian.

Berdasarkan studi pendahuluan, disusun buku referensi menulis faktual berbasis multiliterasi. Buku ini bertujuan membantu mahasiswa untuk belajar mandiri, praktis, mudah dipahami, dan menerapkan keterampilan menulis ragam faktual. Buku referensi menulis faktual berbasis multiliterasi terdiri atas delapan 
bab. Pada bab pertama, membahas ragam genre faktual, mengapa menulis penting? Menumbuhkan kegemaran menulis, dan menulis faktual. Kedua, memaparkan teks deskripsi, definisi teks deskripsi, jenis teks deskripsi, struktur teks deskripsi, menganalisis teks deskripsi, latihan, ragam objek teks deskripsi, contoh teks deskripsi berdasarkan ragamnya, ciri kebahasaan teks deskripsi, latihan, skenario pembelajaran teks deskripsi, rubrik penilaian teks deskripsi, dan latihan. Selanjutnya, bab ketiga membahas teks narasi. Buku ini menguraikan definisi teks narasi, struktur teks narasi, ragam teks narasi, ciri kebahasaan teks narasi, contoh teks narasi, media teks narasi, dan skenario pembelajaran teks narasi.

Pada bab empat, buku tersebut membahas teks eksplanasi. Kelima, memaparkan teks eksposisi. Keenam, membahas teks recount. Ketujuh, membahas teks prosedur. Terakhir, paparan teks berita. Buku referensi tersebut disusun secara runtut dan detail untuk membantu pembaca memahami, menggunakan, dan mengaplikasikan dalam praktik menulis ragam faktual. Untuk mengukur kelayakan buku referensi ini, dilakukan uji materi oleh ahli. Hal ini diperlukan untuk mengetahui buku referensi tersebut layak digunakan sebagai buku referensi dalam menulis faktual. Berikut dipaparkan deskripsi pendapat ahli terkait dengan buku referensi menulis faktual berbasis multiliterasi.

Instrumen kelayakan terbagi dalam empat kriteria penilaian, yaitu: sangat baik, baik, kurang, dan sangat kurang. Selain itu, instrumen kelayakan buku terbagi menjadi tiga aspek, yaitu kelayakan isi, kelayakan penyajian, dan penilaian bahasa. Ketiga aspek diuraikan menjadi beberapa indikator. Pertama, aspek kelayakan isi dengan indikator pertama, kesesuaian materi dengan indikator yang diturunkan dalam butir penilaian (kelengkapan materi, keluasan materi, kedalaman materi). Penilaian ahli materi terkait indikator tersebut adalah berkriteria baik. Indikator kedua, Keakuratan materi yang diuraikan dalam butir penilaian (keakuratan konsep dan definisi, keakuratan fakta dan contoh, keakuratan soal, keakuratan gambar dan tabel, dan keakuratan sumber pustaka). Poin kedua mendapat penilaian dengan kriteria baik.

Indikator ketiga, pendukung materi pembelajaran yang diuraikan dalam butir penilaian (penalaran, keterkaitan, komunikasi, kemenarikan materi, mendorong untuk mencari informasi lebih jauh). Semua butir mendapat penilaian dengan kriteria baik. Indikator keempat, kemutakhiran materi yang diuraikan dalam butir (kesesuaian materi dengan perkembangan ilmu, gambar dan ilustrasi aktual, menggunakan contoh kontekstual, kemutakhiran pustaka). Kesemua poin di indikator mendapat penilaian dengan kategori baik.

Kedua, aspek kelayakan penyajian terdapat empat indikator penilaian, yaitu: teknik penyajian, pendukung penyajian, penyajian pembelajaran, dan kelengkapan penyajian. Secara berurutan keempat indikator diuraikan dalam butir penilaian sebagai berikut: konsistensi sistematika sajian dalam kegiatan pembelajaran, keruntutan penyajian, contoh-contoh soal dalam setiap kegiatan belajar, soal latihan pada setiap akhir kegiatan belajar, rangkuman, keterlibatan mahasiswa, bagian pendahuluan, bagian isi, dan bagian penutup. Pada aspek kelayakan penyajian materi mendapatkan penilaian dengan kategori baik.

Aspek penilaian bahasa terdapat tujuh indikator, yaitu: lugas, komunikatif, dialogis dan interaktif, kesesuaian dengan tingkat perkembangan peserta didik, keruntutan dan kepaduan alur pikir, dan penggunaan istilah. Ketujuh indikator diturunkan dalam butir 
penilaian yaitu: ketepatan struktur kalimat, keefektifan kalimat, kebakuan istilah, keterbacaan, ketepatan penggunaan kaidah bahasa, kemampuan memotivasi pesan atau informasi, kemampuan mendorong berpikir kritis, kesesuaian perkembangan intelektual peserta didik, kesesuaian dengan tingkat perkembangan emosional peserta didik, keruntutan dan keterpaduan antarkegiatan belajar, keruntutan dan keterpaduan antarparagraf, dan konsistensi penggunaan istilah. Keseluruhan butir penilaian dalam kategori baik. Tabel 2 menyajikan ringkasan empat aspek kelayakan buku referensi Menulis Faktual berbasis multiliterasi.

Tabel 2

Kelayakan Buku Referensi Menulis Faktual Berbasis Multiliterasi

\begin{tabular}{ll}
\hline Aspek Penilaian Kelayakan & $\begin{array}{c}\text { Kriteria } \\
\text { Penilaian }\end{array}$ \\
\hline Isi & Baik \\
Pemyajian & Baik \\
Bahasa & Baik \\
Pendekatan dalam referensi & Baik \\
\hline
\end{tabular}

Meskipun penilaian kelayakan oleh ahli dengan kategori baik, buku referensi Menulis Faktual berbasis multiliterasi masih memerlukan revisi pada beberapa bagian. Hal ini terbukti dalam penilaian ahli terhadap buku referensi Menulis Faktual berbasis multiliterasi adalah buku tersebut layak digunakan di lapangan dengan revisi, diperkuat dengan multiliterasi, dan mempertajam tentang penelitian dalam penulisan faktual. Perbaikan perlu dilakukan untuk penyempurnaan buku referensi berbasis multiliterasi.

\section{SIMPULAN}

Berdasarkan hasil penelitian dan pembahasan dapat disimbulkan bahwa pertama, mahasiswa menggunakan buku referensi pada Mata Kuliah Menulis Faktual berupa buku yang terbatas pada sumber referensi di internet, PUEBI, KBBI, dan BSE. Mahasiswa juga mengalami kesulitan dalam memahami buku yang tersedia. Buku referensi yang menarik dan mudah dipahami adalah yang menggunakan bahasa sederhana disertai ilustrasi dan contoh teks berdasarkan objek yang ada di sekitar penulis serta tips menulis ragam faktual yang benar. Kedua, buku referensi menulis faktual berbasis multiliterasi disusun secara runtut dan detail untuk membantu pembaca memahami, menggunakan, dan mengaplikasikan dalam praktik menulis ragam faktual. Ketiga, deskripsi pendapat ahli terhadap produk yaitu buku referensi menulis faktual berbasis multiliterasi dalam kategori layak digunakan dengan revisi, yaitu perbaikan pada penerapan multiliterasi dalam buku dan mempertajam penelitian dalam penulisan faktual.

\section{DAFTAR PUSTAKA}

Abidin, Y. (2014). Desain sistem pembelajaran dalam konteks kurikulum 2013. Bandung: Refika Aditama.

Azizah, I. N., Abidin, Y., \& Yunansah, H. (2015). Penggunan model multiliterasi untuk meningkatkan kemampuan menulis karangan eksposisi. Jurnal PGSD Kampus Cibiru, 3(2).

Haryadi. (2003). Hubungan intensitas mendengarkan ceramah, pemahaman buku teks dan partisipasi berorganisasi dengan retorika. Jurnal Kependidikan, 33(2), 161-180.

KBBI [Kamus Besar Bahasa Indonesia Daring]. (2016). Diunduh dari https:// kbbi.kemdikbud.go.id.

Leksono, S. M., Syachruroji, A., \& Marianingsih, P. (2015). Pengembangan bahan ajar biologi konservasi berbasis etnopedagogi. Jurnal Kependidikan, 45(2), 168-183. 
Lestyarini, B. (2011, Januari). Asesmen autentik dan relevansinya di era multiliterasi. Makalah dipresentaikan dalam Seminar Nasional HEPI. Lampung.

Moedjiarto. (1998). Telaah dan revisi buku ajar karya dosen. Jurnal Kependidikan, 28(2), 265-280.

Pardiyono. (2007). Pasti bisa! Teaching genre-based writing. Yogyakarta:Andi Offset.

Prihandoko, Slamet, St. Y., \& Winarno (2017). Pendekatan cognitive moral sebagai kerangka pengembangan bahan ajar PPKN di sekolah dasar. Jurnal Kependidikan, 1(2), 200-213.

Sari, E. S., Suryaman, M., \& Lestyarini, B. (2011). Model multiliterasi dalam perkuliahan Pendidikan Bahasa dan Sastra Indonesia (Laporan penelitian tidak diterbitkan). Lembaga Penelitian dan Pengabdian kepada Masyarakat,
Universitas Negeri Yogyakarta, Yogyakarta.

Sugiyono. (2011). Metode penelitian kuantitatif, kualitatif, dan $R \& D$. Bandung: Alfabeta.

Suryaman, M. (2012, Mei). Penulisan buku teks pelajaran. Makalah disajikan pada Workshop Penulisan Buku Teks Pelajaran. Universitas Dokter Soetomo, Surabaya.

Syamsi, K., Setiawan, T., \& Suryaman, M. (2017). Evaluasi diri strategi belajar mahasiswa program studi magister pendidikan bahasa Indonesia. Jurnal Kependidikan, 1(2), 348-359.

Takaria, J., \& Talakua, M. (2018). Kemampuan literasi statistik calon guru ditinjau dari kemampuan awal matematika. Jurnal Kependidikan, 2(2), 395-408.

Universitas Negeri Yogyakarta. (2015). Kurikulum 2014 berbasis KKNI. Yogyakarta: Universitas Negeri Yogyakarta. 